\title{
Pursuing Innovation in Micro Business. Is It Possible?
}

\author{
Nia Kurniati Bachtiar ${ }^{*}$ \\ ${ }^{1}$ Department of Management Universitas Muhammadiyah Magelang, Magelang, Indonesia \\ "Corresponding author.Email: niakurniatibachtiar@ummgl.ac.id
}

\begin{abstract}
Innovation is believed as one powerful weapon to survive in modern competitive industry. Both Large organizations (LOs) and Micro, Small and Medium Enterprises (MSMEs) are trying their best to keep up with the innovation within their firms. However, due to its nature in lack of resources both human resource and capital, it is significantly difficult for MSMEs to pursue innovation either in service or product offered. This is an intrinsic qualitative study with a purposive sampling research that aims to reveal the substantial meaning of innovation in MSMEs, which innovation type and approach suit them and strategy in conducting innovation, where it focuses to micro businesses whose owned by college students. These research objects are chosen due to their capability in presenting innovation from their educational background and in-depth knowledge. This study found that 2 (two) out of 3 (three) modern innovation approaches are more essential to be applied to micro business which are inclusive innovation and collaborative innovation. Where the other 1 (one), open innovation is more suitable to LOs. Following to that, this study confirms incremental innovation is the most suitable innovation type among all types. Apart of stating which innovation type and approach fit to student owned micro business, this article also provides the strategic framework to persevere innovation culture in Micro Businesses.
\end{abstract}

Keywords: innovation, micro business, entrepreneurship, incremental innovation, collaborative innovation,

inclusive innovation, entrepreneurs

\section{INTRODUCTION}

"It is not the strongest nor the most intelligent ones who survive, but those who can best adapt to change". This famous quote from Charles Darwin hits every company in every industry all over the world [1]. It can be found easily either in a large or small organization to remind everybody that change is around them. Yes, change is happening, and only the one who can manage that change can survive in the competition.

To be focused in the business industry, change forces companies to adapt and keep up with it and makes company either more mature or die. All companies have dealt with this situation, and some of them ended up miserably, such us: the struggle of Kodak to sustain in industry or the sharp decline of Nokia market share until it sold to Microsoft whom finally sold the Nokia brand to HMD in 2016 [2]. So, to prevent the worst scenario, a company has to push itself to deal with the change. And one most powerful strategy to cope with it is by innovation.

Innovation in definition is "a process which generates value from the creation, development, and implementation of new ideas, technologies, products and services" [3]. The capability of an organization to innovate signifies how well the organization fit itself within every change roll around it. However, there are differences in pursuing innovation capabilities in a small organization and Large Organizations (LOs) due to its size, number of staffs, hierarchy and policy. Literatures have stated that innovation in an essential tool for LOs [4-7]. LOs need to continuity pursue innovation and utilize all layers and departments in their company to involve with the innovation strategy. Question arises: How is it in MSMEs? Especially to Micro Business which have the least resources and capabilities among all businesses size.

The dramatic differences between LO and Micro business may cause the different innovation road map between them $[5,6]$. When LO can easily jump and choose innovation's types and ways suit them. LO has ability to select among 3 (three) types of innovation which are incremental, radical and transformational innovation [8] and innovation approaches such as: inclusive innovation, collaborative innovation and open innovation. They absolutely have plentiful innovation choices to run. Contrast to that, micro business has to encounter huge constrains when it comes to innovation strategy. Then, with all its limitation, question arises: Does micro business has a possibility to innovate? Innovation in small business has been researched by Sahut and Peris-Otiz [11], Roper and Hewitt-Dundar [12], Harris et al [13], Bos-Browers [14], Hallenga-Brink and Brezet [16], Anderson and Loof [18], Tu et al [19]. All literatures discussed the relationship between innovation and small and micro firm. They also emphasized the importance of innovation and providing different insight in order to keep innovating. However, none of them examines which innovation type and approach can be pursued by micro business. in fact, this research is an extended study from previous literature by Faherty and Stephen [17] that indicates the possibility of micro business to innovate. Authors argued that micro business has to define innovation first then choose type of innovation to practice. Nevertheless, it has not stated about innovation approaches need to be undertaken and strategic framework to pursue 
innovation in micro business. Hence, this article will dig deeper to innovation capabilities in micro business and tries to answer the research questions as follows (1) which innovation types appropriate to micro business (2) which innovation approach suit to micro business (3) how to pursue innovation in micro business. Next, the aims of this research include (1) to determine the best innovation type for micro business (2) to emphasize the most suitable innovation approach to micro business (3) to set strategic steps in persevering innovation in micro business. Meanwhile, the novelty of this research covers (1) defining the appropriate innovation's type and approach for micro business (2) providing strategic steps in persevering innovation in micro business.

\section{LITERATURE REVIEW}

To begin with, we need to understand why innovation and innovation capability within organization becomes mainly significant to business existence mostly for micro business. Innovation capabilities in definition means "the ability to come up, consistently, with new ideas that deliver short- and long-term profits to an organization" [9]. Innovation capabilities become important due to both internal and external factors. From internal factors, growth intends to be a trigger to innovate and rising the needs of innovation capabilities, it followed by the shareholder's pressure and lastly, to increase the brand position within the industry. From external factors, changing in customers' preferences, emerging of new competitors and technology development may be the trigger of innovation and again, rising the needs of innovation capabilities

Innovation is not a new topic especially relates to entrepreneurship. Schumpeter as an economic expert firstly announced about the strong and interrelation between small business, innovation and entrepreneurship back in 1934 [10]. After Schumpeter, the magnet of those 3 (three) topics turns wild. Numerous literatures elicit the same topics with variety of research objects, aims and novelty [11-19]. Most discussed about how to pursue innovation in small business, how cooperation can assist small business to innovate to how to sustain innovation in small business. one of them elaborated innovation in micro business, however, it focused to the understanding on innovation and the practice of innovation as general. Hence, this study will bring it forward by focusing to the innovation types and approach compatible to micro business.

\subsection{Types of Innovation}

There are three kinds of innovations can be implemented by the company. They are: incremental innovation, radical innovation and transformational innovation $[15,18,20]$. Each type describes different process to innovate. Incremental represents continuity innovation where every small improvement in either products or service counted. For example: the modification of Windows operating system (OS) where Windows keeps shifting its OS even with a small difference between the previous and the updated version. We recognize Windows NT, Windows 95,
Windows 98, Windows Me, Windows XP, Windows Vista, Windows 7, Windows 8 and the latest one, Windows 10 [19]. Next, radical innovation reflects innovation that shifts whole industry to the next step. One of the hugest radical innovation people experienced was the industrial revolution back in 18th and 19th century when water and animal power were replaced by machinery and steam power [20]. Lastly, transformational innovation represents how huge is technology role in modify whole industry from how things work to time needed to finish one job, the invention of world wide web is the clear example for this type.

The difference between those three not only about how each type changes the business and world, but the impact it carries over time as seen in figure below:

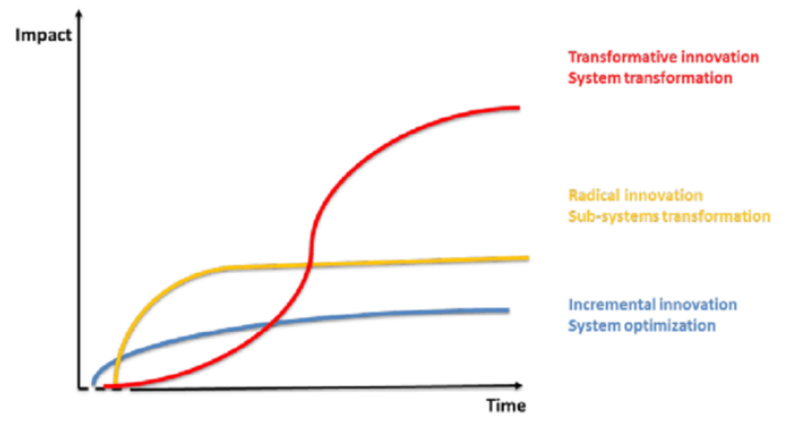

Figure 1. Types of Innovation and the impact [20]

Above figure explain the main different in action among types of innovation. Incremental results system optimization where the impact slightly raises over time. Radical in the same time, raises quite well at the beginning but stagnant over time. Lastly, transformational innovation which has dramatic increasing overtime.

\subsection{Innovation Approach}

In most industries with many big players like automotive industry, technology industry and household industry, organizations who trapped in comfort zone can be easily pointed. It is because most big players/LOs prefer to be predictable, schedule based and enjoy a consistent performance. Being too comfortable in their zones slower them to respond to change and end up late in overcome innovation. At the same time, this modern world creates the development of innovation from what we know previously. Innovation is not only about how company recreate their product or service anymore but it divides into several approach such as: open innovation, collaborative innovation and inclusive innovation.

A report released in 2006 mentioned that $78 \%$ LOs worldwide has adopted Open Innovation (OI) [7]. The advantages resulted from open innovation made this approach is widely implemented. OI can be defined as a valuable idea that emerge from both internal and external company or a process in manage flowing knowledge across organization using mechanism that in line with its business model $[7,21]$ . It also reported that in applying open innovation, there are 2 (two) different classifications such as: inbound innovation and outbound innovation. Inbound innovation relates to 
opening up company's innovation process to external inputs and contributions. It requires company's Research and Development (R\&D) to stay alert with all kind of collaboration in order to succeed this OI method where $P \& G$ is one of the successful examples for this. On the other hand, outbound innovation relates to transfer company's unused idea and asset to be utilized by other companies in their business.

Next, collaborative innovation as the next approach requires partnership between small and young enterprise with wellestablished enterprise. Small and young enterprise has a lot of fresh and sophisticated ideas and human resource and at the same time, wee-established or LO has modern tools, capital and support needed. Esposito [22] in world economic forum added that apart of above partnership, modern collaborative innovation involves both firms in Fast Expanding Market (FEM). The advantage of entering FEM using collaborative innovation is that both firms may discover "a chance to find momentum working together as well as a chance to pursue an immediate business opportunity" [22].

The last approach is inclusive innovation. This approach requires everyone to participate despite of its group, its role in country, its responsibility or its economic status [23]. OECD in 2014 [24] argued that key characteristic of inclusive innovation is that this approach is accessible for low income populations.

\subsection{Sustainable Innovation}

People in common think that innovation belongs to a certain department within the industry or becomes the responsibilities of the top managers only. However, all layers in it should be empowered to innovate from the lower layers such us customer services, coordinators, chief of all departments, middle managers to top level managers. This thought was strengthened by the data from 2006 that the highest percentage of the source of innovation in an organization didn't come from R\&D Department but its employees, followed by the business partners and customers [3].

Innovation produces new product/service for the organization. However, every product/service has its time period that has to be realized and anticipated by the organization. The spread of that period can be seen in the graph below:

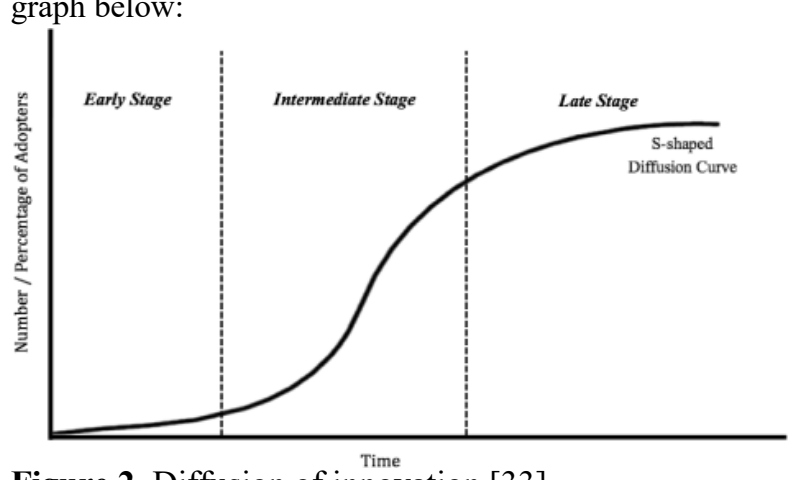

Figure 2. Diffusion of innovation [33]
The graph above called diffusion of innovation shows everyone that period of a product/service will not last forever. Every product will be in tipping point when it's introduced to the market and raise up by helping of sales, marketing, distribution and even by helping of globalization. And finally, it stops climb and starts to be stagnant, and it attains tripping point. Declining will start after that point and turn the organization to a depressed situation.

Therefore, to be able to stay innovative, a firm should keep its innovation process continuity or it generally known as sustainable innovation. In innovation strategy, we are wellaware with the concept of S-Curve in innovation. The appropriate moves a firm can apply is by implementing more than one $\mathrm{S}$ curve as seen in the graph below:

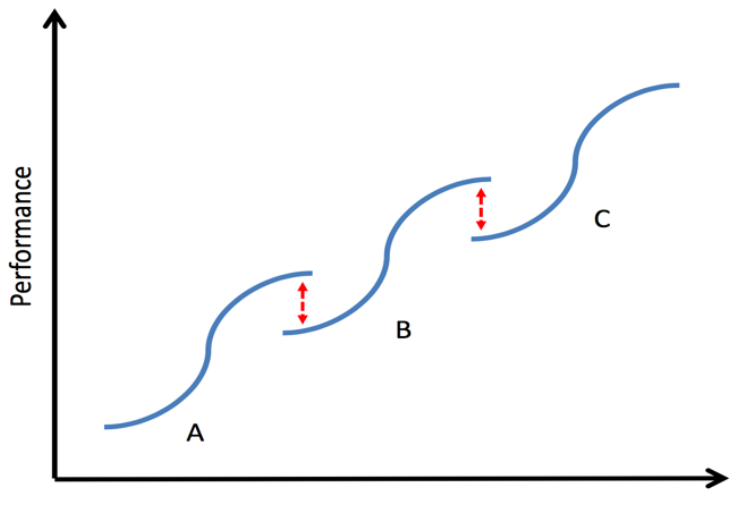

Figure 3. S Curve [3]

Time / Effort / R\&D Spend

The curve above strongly suggests the organization jump to another innovation process before the previous product/service reach the tripping point. And it'll continue the same process until it's time to move to another curve. Implementing this curve especially in a large organization will assist the CEO in running their organization towards every change and rapid competition in industry.

In order to face the competition, an organization needs to use their capabilities as a weapon to win the market. So that, innovation capabilities become one of the significant keys to reaching that target. By innovation, the organization is able to convert the new know-how becomes a new product, process or service and in the end carries the organization to the better position in industry.

Addition to that, there were misunderstandings of most managers especially that assume innovation is all about new products and new technology only. But intensively, innovation is applied to new service, business model, pricing plan, how to attract market and new management practice [25].

\section{METHODS}

There are 5 (five) choices in research strategy. They are experiment, written survey, document analysis, historical study, and case study [26]. The authors stated that case study research can be conducted in contemporary event where contextual event need to be analyzed. This explanation completed Eisenhardt [27] that underlined that 
case study research is an empirical study where both quantitative and qualitative methods can be utilized. Identifying the problem or phenomena becomes the first step in building a case study research. Once problem has identified, theory is needed to link the literature and the data. Selecting criteria's, constraints, attributes to narrow down the sample will be the next step to finally write the result and report. Yin [28] claimed that case study research may contribute in defining the problem and building theories. The author also added the characteristic requirement for this research such as: it should help in constructing theories, it should accommodate indirect observation, can be used in quantitative and qualitative study and should help in finding generalization.

In fact, this study a qualitative based research. It means data gathered and resulted will be based on qualitative perspective. Population of this research were students in Management Study based in Universitas Muhammadiyah Magelang. Students in management study have been taught about innovation in several courses during their study and also been taught innovation management course as a compulsory course in their $7^{\text {th }}$ semester. According to the research conducted for this study, among 482 students in management in 2019, 71 of them having their own business. In the end, 17 case studies are selected. These case studies represent the business in food and beverage, professional training, textile, handmade craft, education and service.

\section{RESULTS AND DISCUSSION}

Innovation as stated before is a core to business sustainability. Without doing it, both LOs and MSMEs will struggle to survive. However, due to the lack of resources in micro business as it classified as a business that have less than 10 (ten) employees and have income no more than $€ 2$ million [29], it is hard to pursue innovation in it. This part will discover how micro business should keep up with innovation within their firms.

\subsection{Challenge in Innovation in Micro Business}

With a micro-management who are already struggle with daily routines, pursuing innovation is not a priority [17]. Inline to that, literatures have listed several limitations in micro business, they are: the absence of management consultant, focus in short term strategy, the presence of dominant competitors, inadequate information, limited ability to recruit, lack of partnership and lastly, lack of finance $[17,30,31]$. These findings are supported by comment from interviewees such as:

"Lack of capital is the main reason it is hard for me to innovate" All interviewees

"There are some big competitors here in Magelang and if

I have to face them one-to-one, I think I will get the disadvantage" Interviewee [3,10,11,13]

Apart of above reasons, this study also discovers more customized and case-based reason why those micro businesses are forced not to innovate as mentioned below:
"I didn't use to think that I need to innovate since I only run my business as usual" Interviewee 2,4,5,7,8,9

"Apart of capital, I have to admit that my own capabilities and knowledge hinder me to innovate" Interviewee 6,13,16

"For me, the most difficult one is time management. Innovation need a lot of time to pursue and We are all students that have been busy enough in campus" All interviewees

Hence, even though it has stated in literatures that innovation and innovation capabilities are important due to many factors, however, barriers to innovate are quite complex and complicated for micro business.

\subsection{Types of Innovation in Micro Business}

All businesses need to innovate in spite of challenges faced. When LOs barriers to innovate relate more to the complex bureaucracy, technology adoption, being too comfortable, persuasion and power [32], micro business has to encounter different challenges. Hence, to simplify those complexity to innovate, literatures has emphasized types of innovation can be pursued to specify its innovation process $[15,18,20]$. As stated in literature review above, types of innovation start with incremental innovation which counted every single innovation even though it is only a small improvement. Graph used above shows that incremental innovation has a stagnant impact overtime. Following to that, radical innovation represents a sub-system transformation in a business and have higher impact than incremental. However, it is also moving straight overtime. Lastly, innovation that is able to transform a whole world and have gradually increasing impact overtime is called transformational innovation [20].

For this study, all interviewees agree that they have not been able to commit radical and transformational innovation as some of them declared:

"How can we do such changing to the industry we're in? We're not capable to do so" Interviewee 1

"When it relates to technology, I don't think I can do a lot" Interviewee 13

"Radical and transformational need a lot of resources we don't have" interviewee 17

However, they are agreeing that all of them can perform incremental innovation within their businesses as mentioned:

"I have learnt innovation management in class and I know I can keep improving my socks (product) a bit by a bit by doing something from my lecture" Interviewee 7

"We always keep up with trend and I think We are innovating in its way" Interviewee 8,12,16

"Incremental is the easiest one since it is need less power than the others" Interviewee 4

\subsection{Innovation Approach in Micro Business}

As described earlier, there are 3 (three) approaches in innovation, namely open innovation, collaborative innovation and inclusive innovation [7,21-24]. Open innovation describes the ability of a business to open up with outside input and vice versa [7,21]. Collaborative innovation involves LOs and small firms in pursuing 
innovation [22] and lastly, inclusive innovation that implicate all subjects to innovate $[23,24]$. Since research objects have been familiarized with these terms, it is convenient to get their comment for each of them.

Again, alike the previous question, all interviewees have same opinion for this question as well. They believe that collaborative innovation and inclusive innovation are the most suitable innovation approaches for them, as they argued:

"I open to collaborate with anyone both LOs and small firm, both individual and group. So, collaborative is the one I choose" Interviewee 3

"Inclusive innovation allows us to establish cooperation with anyone. I prefer this one" Interviewee 11,14,16

"Can we perform both of them? I think it is preferable option" Interviewee 1,3,5,6,9

As stated in literature review earlier, open innovation is appropriate for LOs due to its requirements needed. Hence, especially for micro business, this finding supports literatures that collaborative and inclusive innovation are 2 (two) approaches that can be exploited by micro business [22-24].

\subsection{Innovation Lecture and Desire to Innovate}

1 (one) the sample category for this research is students who have been taught innovation management lecture in campus. Therefore, they have been aware of the importance of innovation and how to pursue innovation in their business. For that category, this study tried to confirm the relation between the knowledge they gain from campus and their decision and desire to innovate. The result is described as:

"I have a grand picture of innovation through the lecture, however I still don't have the courage right away" Interviewee 8,9,12,14

"The lecture taught us a lot. I can practice it in my business especially the innovation type that suitable for my business" interviewee 2,4,7,11,17

"This lecture makes me aware the importance of innovation. I'll practice it someday" interviewee 5,6,15 Consequently, the lecture is carrying an impact to students. However, it is significant to remember that courage in doing something is not as simple as teaching theory to students. It requires more in-depth approach and a lot of practice in order to do so.

\subsection{Innovation Strategy in Micro Business}

Discovering such findings, it can be concluded that micro business is in need in innovation as LOs do. However, innovation is not enough, micro firm has to be able to perform sustainable innovation through implementing innovation type, innovation approach and specifically adapt the S-curve of innovation [3].

Therefore, this part will provide strategic action micro business can adopt in order to pursue innovation within firm. The strategic action will be formed in a framework to simplify the adoption steps as cited from interviewees:
"I think I know the theory, I read books but I still need assistance in doing it directly" Interviewee 15

"The concept is still scattered around in my brain and I don't know how to put them in order" Interviewee 4,6,7,17 For above cause, this research tries to put all the findings in one framework to be applied by micro business as seen in figure below:

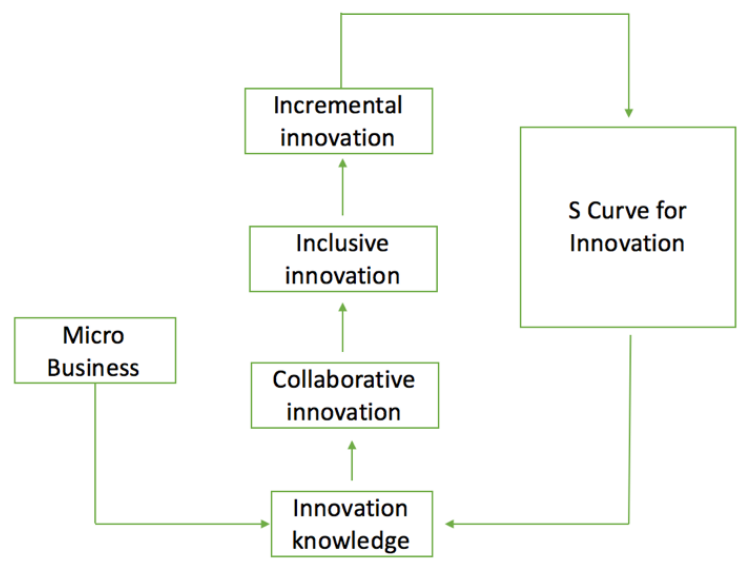

Figure 4 Proposed framework

Above figure explains that micro business should possess innovation knowledge from the beginning. This knowledge then results innovation awareness that keep them alert of the importance of innovation. By that knowledge, micro business can pursue innovation by committing collaborative innovation to finally involve in inclusive innovation. Both approaches are adapted to shape and create incremental innovation in their firms. Finally, all strategies are implemented by using S-Curve for innovation. All the process above are continuity to generate sustainable innovation to finally develop a sustainable business.

\section{CONCLUSION}

Innovation is a powerful weapon to survive in the industry. It is applied for both LOs and micro business. This research finds out that micro business has to encounter different barriers to innovate from LOs and in order to minimize the barriers some innovation strategies can be implemented. Firstly, the suitable type on innovation can be implemented is incremental innovation, where micro business should innovate step by step, gradually and keep improving over time. Next, micro business should adopt 2 (two) innovation approaches namely collaborate innovation and inclusive innovation. Lastly, this paper provides strategic framework in innovation for micro business. using those approaches, type and framework, this study confirms that micro business still can pursue innovation. This study is limited to students in management study based in Universitas Muhammadiyah Magelang. Hence, it has strong internal validation in data gathering and collection. However, it has weak external validation due to the limited scope. Therefore, this paper suggests this research to be conducted in larger population and area to get broader picture and validation, especially for external validation. In the end, this study wishes that result 
[12] Roper, S., \& Hewitt-Dundas, N. (2017).

Investigating a neglected part of Schumpeter's creative army: what drives new-to-the-market innovation in micro-enterprises? Small Business Econ, 559-577.

[13] Harris, R., McAdam, R., McCausland, I., \& Reid, R. (2013). Levels of innovation within SMEs in peripheral regions: the role of business improvement initiatives. Journal of Small Business and Enterprise Development, 102-124

[14] Bos-Brouwers, H. E. (2010). Corporate Sustainability and Innovation in SMEs: Evidence of Themes and Activities in Practice. Business Strategy and the Environment, 417-435

[16] Hallenga-Brink, S., \& Brezet, J. (2005). The sustainable innovation design diamond for micro-sized enterprises in tourism. Journal of Cleaner Production, $141-149$

[17] aherty, U., \& Stephens, S. (2016). Innovation in micro enterprises: reality or fiction? Journal of Small Business and Enterprise Development, -

[18] Andersson, M., \& Loof, H. (2012). Small business innovation: firm level evidence from Sweden. J Technol Transf, 732-754

[19] Tu, C., Hwang, S.-N., \& Wong, J.-Y. (2014). How does cooperation affect innovation in microenterprises? Management Decision, 1390 - 1409

[20] Hall, A., Dijkman, Jeroen, Taylor, Bruce, Williams, . . Jennifer. (2016). Synopsis: Towards a framework for unlocking transformative agricultural innovation. -: Independent Science and partnership Council

[21] Chesbrough, H. (2003). Open Innovation: The New Imperative for Creating and Profiting, from Technology. Harvard Business School Press, 43

[22] Esposito, M. (2015, August 5). World Economic Forum. Retrieved from World Economic Forum: https://www.weforum.org/agenda/2015/08/the-5-rulesof-collaborative-innovation/

[23] Heeks, R., Amalia, M., Kintu, R., \& Shah, N. (2013). Inclusive Innovation: Definition, Conceptualisation and Future Research Priorities. Development Informatics Working Paper, - .

[24] Dahlman, C. (2014, July 1). OECD. Retrieved from OECD:

https://www.oecd.org/sti/inno/OECD_GFD2014_Dahl man_InclusiveInnovation_2July2014.pdf
[11] Sahut, J.-M., \& Peris-Ortiz, M. (2013). Small business, innovation, and entrepreneurship. Small Business Econ, 663-668. 
[30] Salavou, H., Baltas, G., \& Lioukas, S. (2004). Organisational innovation in SMEs: The importance of strategic orientation and competitive structure.

European Journal of Marketing, 1091-1112.

(2008). Case Study Method for Design Research: A Justification. -: Proceedings of the ASME Design

Engineering Technical Conference.

[27] Eisenhardt, K. (1989). Building Theories from Case Study Research. The Academy of Management Review, 532-550.

[28] Yin, R. (2003). Case study research : Design and Methods, . -: Sage Publications.

[29] Forbes. (2018, August 2). Forbes. Retrieved from Forbes:

https://www.forbes.com/sites/davidhowell1/2018/08/02

/want-to-start-your-own-micro-

business/\#6750a 4e13c60
[31] McAdam, R., McConvery, T., \& Armstrong, G. (2004). Barriers to innovation within small firms in a peripheral location. International Journal of Entrepreneurial Behaviour \& Research, 206-221.

[32] Chui, M (2005). How big companies can innovate. Available from: http://www.mckinsey.com/businessfunctions/strategy-and-corporate-finance/ourinsights/how-big-companies-can-innovate [Assessed 20 August 2019]

[33] Xiong, H., Wang, P., \& Bobashev, G. (2018). Multiple peer effects in the diffusion of innovations on social networks: a simulation study. Journal of Innovation and Entrepreneurship. 